\title{
PARALLEL REALITY OF STATE DEFENCE ORDER
}

\author{
V.Zatsepin
}

The State Defense Order 2012 was implemented nearly 80\%. Being limited in labor force, Russia's defense plants are facing problems related to drastically increased the State Defense Order 2013. President Putin's requirements to create a transparent military economy, establish order in terms of administration in the military-industrial complex and its pricing have encountered serious difficulties.

A final conclusion of the Accounts Chamber of the Russian Federation on a draft Federal Law "On the Implementation of the Federal Budget for 2012" was posted on the State Duma's official website on September 17, 2013. The conclusion shed light on certain considerations related to the implementation of the State Defense Order (SDO) in 2012 $2^{1}$.

The fact of further cut offs in the SDO 2012 adopted in the Russian Government's Executive Order dd. October 22, 2012 No. 1076-21 and December 22, 2012 No. 1385-31 "with regard to the procurement of weaponry, military and special equipment (WMSE), including the 10 tasks which are considered as toppriority" 2 was finally confirmed. The Accounts Chamber of the Russian Federation pointed out that "products for the procurement and repair of WMSE were short-delivered under 121 concluded public contracts, including 65 contracts on the procurement of WMSE, 56 contracts on the repair of WMSE". Eighteen of the defense-related R\&Ds failed to be completed in due time in the previous year, of which 35 were fully paid and 26 implemented over a period of 20 years and beyond. Yet, as is known, it didn't stop those in charge to report the $99 \%$ implementation of the SDO at the very beginning of $2013^{3}$.

The Accounts Chamber's data confirms the statement made in June 2013 by Head of the Military Rep-

1 ЗаключениеСчетнойпалаты РоссийскойФедерациинаотчет об исполнении федерального бюджета за 2012 г. (утверждено Коллегией Счетной палаты Российской федерации, протокол от 30 августа 2013 г. № 35К (926). № 3СП-19/15-10. М., 2013. 491 c. [The Accounts Chamber of the Russian Federation Report on the implementation of the Federal Budget for 2012. (Approved by the Board of the Accounts Chamber of the Russian Federation, Protocol dated August 30, 2013, No. 35K (926). No. ZSP-19/15-10. M., 2013. P.491]URL: http://asozd2.duma.gov.ru/main.nsf/(ViewDoc)? OpenAgent\&work/dz.nsf/ByID\&597281A07886E03D43257BDA00 4C1BB8 (access date: 28.10.2013).

2 Ibid. C. 215.

3 Дмитрий Рогозин дал интервью телеканалу «Вести» по итогам селекторного совещания о гособоронзаказе. Стенограмма. М., 21 января 2013. [Dmitri Rogozin gave interview to Vesti TV channel on the results of a telephone conference on the State Defense Order. Shorthand report. M., January 21, 2013]URL: http://government.ru/vice_news/296 (access date: 28.10.2013). resentative Office under the Ministry of Defense of the Russian Federation O. Stepanov that the Russian defense industry short-delivered "nearly $20 \%$ of military (defense) products" to the Russia's Armed Forces in $2012^{4}$. It is particularly remarkable that a relative value of the last-year short-delivery under the SDO corresponded well with a $19.6 \%$ nominal growth in the federal budget expenditures under the 'National Defense' line in 2012. Judging by this, our defense industry can't be equal to the Government's task of reaching the $15 \%$ annual growth in the output of military (defense) products ${ }^{5}$, and drastic increase in the SDO financing provided for by the ongoing State Armament Program for 2011-2020 (SAP) set apparently impossible tasks for the industrial sector and discouraged it to enhance its effectiveness.

The developing situation has been soberly evaluated by the Military-Industrial Commission under the Government of the Russian Federation and at the Ministry of Defense of the Russian Federation. For instance, Military-Industrial Commission Deputy Chairman O. Bochkarev stated in August 2013 that certain enterprises' order volume almost doubled and growth rates stood at $25-40 \%$ in general at enterprises of the military-industrial complex (MIC), and that "it is a hardship for our colleagues in the industry to achieve such values" ${ }^{\prime \prime}$. In addition, Deputy Minister of Defense for Armament Y. Borisov confirmed during his visit to the Primorye Territory in October 2013 that "many-fold increase in the volume of works on the side of Minis-

4 «Оборонка» недопоставила Вооруженным силам в 2012 г. 20\% продукции // INTERFAX.RU. 2013. 25 июня. [ // INTERFAX.RU. June 25, 2013 ] URL: http://www.interfax.ru/print. asp?sec=1448\&id=314761 (access date: 28.10 .2013 ).

5 Рабочая встреча с Заместителем Председателя Правительства Дмитрием Rogozinым. Ново-Огарево, 21 марта 2013. [A working meeting with Deputy Prime Minister of Russia Dmitri Rogozin. Novo-Ogarevo, March 21, 2013.] URL: http://www. kremlin.ru/news/17719 (access date: 29.10.2013).

6 Деятельность Военно-промышленной комиссии и гособоронзаказ // Эхо Москвы. 2013. 12 августа. [The MilitaryIndustrial Commission and the State Defense Order // Echo of Moscow. August 13, 2013.] URL: http://echo.msk.ru/programs/ arsenal/1132844-echo/ (access date: 28.10.2013). 
try of Defense of the Russian Federation constitutes a common problem" and "qualified personnel training is our heel of Achilles"1.

It is pointless to dispute the fact that labor force has become the key factor constraining MIC output growth. According to Member of the State Duma Defense Commission A. Zhuravlev, today the Russian MIC enterprises have almost 900,000 employees (at an average age of 46) and about 440,000 are employed at research institutions (at an average age of 48 ), running short of engineer technologists (17\%), designing engineers (22\%), and blue-collar personnel (40\%)

In spite of that, as early as June 2013 Deputy Minister of Economic Development A. Klepatch estimated approximately a 19\% growth in MIC output in 2013 and a $15 \%$ annual average growth in the period between 2014 and 2016, although he admitted that "we have a huge military-industrial complex which earns very little"3. He also said that the share of the MIC "is too big indeed, accounting for as little as $5 \%$ of the industrial sector and almost one third of the machine building industry"4. It should be noted that with regard to the latter A. Klepatch totally disagreed with Deputy Prime Minister of the Russia D. Rogozin who noted some time ago that our defense sector or 'defense segment', as he put it, "is huge and much bigger than the rest of non-defense economy" ${ }^{5}$. Perhaps, this is why D. Rogozin defends so easily an unbridled build-up of military expenditures in the federal budget, considering the MIC the goose "that lays the golden eggs" . According to Rogozin, "various industries show $12-14 \%$ of growth in production output, in particular

1 Борисов: проблема завода «Звезда» в Приморье недостаток кадров // РИА Новости. 2013. 10 октября. [Borisov: Zvezda Plant, in the Primorye Territory, faces the issue of personnel shortage // RIANOVOSTI. October 10, 2013.] URL: http://ria.ru/ $\mathrm{vl} / 20131010 / 968929045 . h t m l$ (access date: 28.10.2013).

2 Законодательная поддержка оборонно-промышленного комплекса // Эхо Москвы. 2013. 26 августа. [Legislative support of the Military-Industrial Complex // Echo of Moscow. August 26, 2013.] URL: http://echo.msk.ru/programs/ arsenal/1142000-echo/ (access date: 28.10.2013).

3 Оборонные гарантии России // Красная звезда. 2013. 29 июня (№ 112). [Defense guarantees of Russia // Krasnaya Zvezda. June 29, 2013. (No. 112) ] URL: http://www.redstar.ru/index. php/newspaper/item/9939-oboronnye-garanti (access date: 28.10.2013).

4 Ibid.

5 Эксклюзивное интервью итоговой программе «Сегодня» (38'00") // Канал НТВ. 2012. 25 ноября. [An exclusive interview to the Segodnya TV program (38'00") // NTV Channel. November 25, 2012.] URL: http://www.ntv.ru/novosti/372478/ (access date: 28.10 .2013$)$.

6 ОПК России: 20 лет спустя... // Военно-промышленный курьер. 2013. 9 октября (№ 39). [The Russian MIC: 20 years on... // Voenno-promyshlenny Kuryer. October 9, 2013. (No. 39). ]

URL: http://www.vpk-news.ru/articles/17722 (access date: 28.10.2013). in the aircraft and shipbuilding industries, and electronics industry. Now it goes behind nothing but wage increase, but in general its increase "in the defense industry" ranged within a significant figure of $23 \%$ and $25 \%$ annually"7.

In August 2013 the Rosstat (Federal State Statistics Service) published itemized statistical data on the production account and gross value added deflators for 2011 and 2012. Though the data, of course, neither deny nor confirm the Deputy Prime Minister's words, it allow one to assume that defense industry's output growth within the first two years of the SAP for 20112020 is at least compensated by a decline in output of non-defense products in the MIC basic industries, and the aforementioned wage increase is not linked with labor productivity. Furthermore, a visible effect of termination of so called 'price wars' with the Ministry of Defense of the Russian Federation in the shipbuilding industry in 2012 should be highlighted.

Early in October 2013 an information leaked to mass media about likely changes to the current federal budget, in particular with regard to a $\mathrm{Rb} 35,3 \mathrm{bn}$ cut off in arms procurement of the Ministry of Defense of Russia and Rb 21,6bn of military pay costs, with the saved resources being allocated to capital construction related to the state armament program ( $\mathrm{Rb} 43,6 \mathrm{bn}$ ) and compensation for growth in tariffs of natural monopolies ${ }^{8}$. However, a Rb 58,6bn cut off in classified budget allocations to the Ministry of Defense of the Russian Federation in the draft Federal Law of October 22, 2013 ${ }^{9}$ is indicative of that the Ministry of Defense's arms procurement will be cut off to a far greater degree than it was expected just a month ago, thereby resembling a lot the aforementioned situation with amendments to the SDO in 2012.

Both the manner in which Prime Minister D. Medvedev admitted the bias "towards financing of expenditures on the military-related component" at a meeting with members of the Board of the Council of Federation in September $2013^{10}$ and the measures the Government and the Military-Industrial Commission

\section{Ibid.}

8 На чем сэкономит и на чем экономит новая версия бюджета-2013 // Коммерсантъ. 2013. 7 октября. [What the new version of the 2013 federal budget will save and saves on // Commersant. October 7, 2013. ] URL: http://www.kommersant.ru/ doc/2313985 (access date: 28.10.2013).

9 Законопроект № 365264-6 «О внесении изменений в Федеральный закон “О федеральном бюджете на 2013 год и плановый период 2014 и 2015 годов"». [Draft Federal Law No. 365264-6 "On the Amendments to the Federal Law "On the Federal Budget for 2013 and the Planning Period of 2014 and 2015" ] URL: http://asozd2.duma.gov.ru/main.nsf/\%28SpravkaNe w\%29?OpenAgent\&RN=365264-6\&02 (access date: 28.10.2013).

10 Дмитрий Медведев встретился с членами Совета палаты Совета Федерации. Стенограмма. М., 23 сентября 2012. [Dmitri 
proposed during this year for improving the situation with the SDO implementation (the Military-Industrial Commission Operation Headquarters (which holds weekly meetings), a SDO task team under the public prosecutor's office, an increase in legislative pressure upon those who commit violations), as well as expectations of a new version of the SDO law ${ }^{1}$ to enter into force in January 2014 after the adoption of eight additional Executive Orders by the Russian Government could do nothing but create the impression of unbreakable deadlock for Russia.

Medvedev met with the members of ] URL: http://government.ru/ news/5990 (access date: 28.10.2012).

1 О государственном оборонном заказе: федер. закон Рос. Федерации от 29 декабря 2012 г. № 275-Ф3: принят Гос. Думой Федер. Собр. Рос. Федерации 19 дек. 2012 г.: одобр. Советом Федерации Федер. Собр. Рос. Федерации 26 дек. 2012 г. // Рос. газ. - 2012. - 31 декабря. [On the State Defense Order: the Federal Law dd. December 29, 2012, No. 275-FZ: adopted by the State Duma of the Russian Federation on December 19, 2012: approved by the Council of the Federal Assembly of the Russian Federation on December 26, 2012 // Ros. Gaz. - December 31, 2012].
Therefore, the recent Military-Industrial Commission Deputy Chairman O. Bochkarev's statement about likely establishment of an auditing framework to control pricing in the Russian $\mathrm{MIC}^{2}$ should be viewed with a certain hope. Perhaps, this is the chance for the Russian government authorities to finally manage to implement the idea of monitoring prices of products by their studying which was formulated in 1916 by then Ministry of Finance L. Bark, almost 100 years ago ${ }^{3}$.

2 Военно-промышленная комиссия задумалась об аудиторах цен в «оборонке» // РИА Новости. 2013. 23 октября. [The Military-Industrial Commission thinks about price auditors in the defense industry // RIANOVOSTI. October 23, 2013.] URL: http:// ria.ru/defense safety/20131023/972113639.html (access date: 28.10.2013).

3 Воронкова С.В. Материалы Особого совещания по обороне государства. Источниковедческое исследование. М.: Издательство МГУ, 1975. С. 162. [Voronkova S. V. The materials of a special national defense meeting. Historiographic study. M.: MSU Publishing House, 1975. P. 162]. 